\title{
Perencanaan Pondasi Rakit dan Pondasi Tiang Dengan Memperhatikan Differential Settlement "Studi Kasus Gedung Fasilitas Umum Pendidikan Universitas 17 Agustus 1945 Surabaya (Untag)"
}

\author{
Hartono, Indrasurya B. Mochtar dan Musta'in Arif \\ Jurusan Teknik Sipil - Fakultas Teknik Sipil dan Perencanaan, Institut Teknologi Sepuluh Nopember (ITS) \\ J1. Arief Rahman Hakim, Surabaya 60111 Indonesia \\ Email : indrasurya@its.ac.id ; arifmustain@yahoo.com
}

\begin{abstract}
Abstrak-Pondasi diperlukan untuk mendukung beban bangunan diatasnya. Pondasi tiang umumnya digunakan untuk bangunan sedang sampai tinggi. Namun apabila kedalaman tanah keras jauh dari permukaan pengunaan pondasi tiang dapat menjadi tidak ekonomis. Pondasi juga harus direncanakan dengan memperhatikan perbedaan penurunan (differential settlement) karena dapat menyebabkan retakretak pada bangunan sehingga kenyamanan penghuni terganggu akibat adanya retak tersebut.

Studi ini dilakukan untuk merencanakan pondasi rakit dan tiang dengan memperhatikan perbedaan penurunan studi kasus pada "Gedung Fasilitas Umum Pendidikan 17 Agustus 1945 Surabaya (UNTAG") serta membandingkan biaya bahan antara pondasi rakit dan pondasi tiang. Gedung Fasilitas Pendidikan Universitas 17 Agustus 1945 Surabaya (UNTAG) ini dibutuhkan untuk menunjang kegiatan perkuliahan. Gedung ini memiliki luas $6.480 \mathrm{~m} 2$ dan berjumlah 9 tingkat. Pondasi rakit yang direncanakan memiliki panjang dan lebar 44x42 meter dikedalaman 3 meter dibawah permukaan tanah. Pada pondasi tiang pancang direncanakan menggunakan pondasi tiang D60 dengan kedalaman mencapai 30 meter.

Hasil dari penelitian ini yaitu pada pondasi rakit terjadi differential settlement melebihi batas toleransi yaitu 0.0015 (NAVFAC, DM-7). Untuk menghilangkan penurunan konsolidasi dibutuhkan perbaikan tanah dengan PVD dan preloading. Sedangkan pada pondasi tiang menumpu pada tanah keras dikedalaman $30 \mathrm{~m}$ sehingga tidak terjadi penurunan konsolidasi. Adapun alternatif yang dipilih pada kasus ini yaitu menggunakan tiang pancang penurunan tanah (settlement) tidak menjadi masalah sehingga tidak diperlukan perbaikan tanah terlebih dahulu.
\end{abstract}

Kata kunci - Pondasi Rakit, Preloading, PVD, Tiang Pancang, Settlement.

\section{PENDAHULUAN}

$\mathrm{D}^{\prime}$ ALAM mencapai tujuan pendidikan perguruan tinggi, diperlukan sarana dan prasarana yang baik. Prasarana mencakup lahan dan bangunan untuk keperluan ruang kuliah, ruang dosen, dan lainnya. Oleh sebab itu, gedung fasilitas umum pendidikan Universitas 17 Agustus 1945 Surabaya (UNTAG) akan dibangun untuk menunjang kegiatan perkuliahan. Gedung ini terdiri dari 10 lantai dan direncanakan menggunakan pondasi KSLL seri 3 dengan perkuatan cerucuk bambu.

UNTAG sebagai owner telah menerapkan sistem pondasi KSLL pada beberapa gedungnya. Walaupun ada kecenderungan dalam memilih sistem pondasi KSLL, ada pertimbangan dari owner sebelum memutuskan pondasi yang akan digunakan. Yaitu bagaimana jika digunakan sistem pondasi selain sistem pondasi KSLL. Maka diperlukan studi untuk mengetahui bilamana digunakan sistem pondasi yang lain pada gedung tersebut. Dalam hal ini dipilih pondasi tiang dan pondasi rakit yang akan digunakan pada gedung tersebut

Pondasi tiang meneruskan beban hingga mencapai tanah keras. Namun, apabila tanah keras terlalu dalam sehingga tidak dapat dicapai, pondasi tiang dapat bekerja dengan meneruskan beban ke tanah melalui tahanan geser yang timbul akibat dengan gesekan antara tanah dan pondasi. Biasanya beberapa pondasi tiang digunakan dan disatukan oleh poer (pile cap). Sedangkan bila tanah dengan daya dukung rendah biasanya digunakan pondasi rakit. Pondasi rakit mendukung beberapa buah kolom dalam sebuah pelat beton (concrete slab).

\section{METODOLOGI}

\section{A. Studi Literatur}

Studi literatur yang dimaksudkan adalah mengumpulkan materi-materi yang akan digunakan sebagai acuan dalam melakukan perencanaan. Adapun bahan yang nantinya digunakan sebagai acuan dalam melakukan perencanaan adalah sebagai berikut :

1. Teori daya dukung pondasi rakit

2. Teori daya dukung pondasi tiang pancang

3. Perhitungan defleksi pondasi tiang

4.Perhitungan penulangan pondasi

5. Perhitungan penurunan tiang pancang dan pondasi rakit

\section{B. Pengumpulan dan Analisa Data}

Data-data yang digunakan dalam perencanaan ini adalah data sekunder. Data tersebut meliputi :

1. Denah bangunan

2. Data pengujian tanah di lapangan

3. Data perhitungan beban struktur

\section{Perencanaan Pondasi Rakit}

Melakukan perencanaan dengan menggunakan sistem pondasi rakit dengan memperhatikan adanya differential settlement yang terjadi. Mengetahui dimensi pondasi rakit yang dibutuhkan. Melakukan kontrol terhadap struktur pondasi dan menghitung penulangan yang dibutuhkan.

D. Perencanaan Pondasi Tiang Pancang 
Melakukan perencanaan dengan menggunakan sistem pondasi tiang dengan memperhatikan adanya differential settlement yang terjadi. Mengetahui dimensi poer dan banyaknya pondasi tiang pancang yang dibutuhkan. Melakukan kontrol terhadap struktur pondasi dan menghitung penulangan yang dibutuhkan,

\section{E. Perhitungan Biaya Material}

Setelah merencanakan pondasi, maka dilakukan perhitungan biaya material untuk mengetahui besarnya biaya yang dibutuhkan untuk masing-masing pondasi.

\section{HASIL DAN PEMBAHASAN}

\section{A. Analisa Data Tanah}

Hasil korelasi antar hubungan parameter tanah serta parameter hasil uji laboratorium yang diperoleh seperti terangkum dapat dilihat Tabel 1.

Tabel 1.

Data tanah

\begin{tabular}{|c|c|c|c|c|c|c|c|c|c|c|c|c|}
\hline Kedalaman & Jenis & Gs & e & $\mathrm{Sr}$ & $W_{c}$ & $\mathrm{n}$ & Y & $\mathrm{Yd}$ & Ysat & $\phi^{\prime}$ & $C^{\prime}$ & $\mathrm{Cu}$ \\
\hline $\mathrm{m}$ & Tanah & & & $\%$ & $\%$ & $\%$ & $\mathrm{gr} / \mathrm{cm}^{3}$ & $\mathrm{gr} / \mathrm{cm}^{3}$ & $\mathrm{gr} / \mathrm{cm}^{3}$ & 0 & $\mathrm{~kg} / \mathrm{cm}^{2}$ & $\mathrm{~kg} / \mathrm{cm}^{2}$ \\
\hline & & & & & & & & & & & & \\
\hline-3 & Lempung Berpasir & 2.724 & 1.515 & 100 & 55.61 & 60.23 & 1.686 & 1.083 & 1.686 & 0 & ${ }^{*}$ & 0.05 \\
\hline-6 & Lempung & 2.715 & 1.504 & 100 & 55.4 & 60.06 & 1.685 & 1.084 & 1.685 & 0 & 8 & 0.08 \\
\hline-9 & Lampung & 2.703 & 1.468 & 100 & 54.31 & 59.48 & 1.69 & 1.095 & 1.69 & 0 & 8 & 0.09 \\
\hline-12 & Lempung & 2.687 & 1.497 & 100 & 55.71 & 59.95 & 1.676 & 1.076 & 1.676 & 0 & $*$ & 0.25 \\
\hline-15 & Lempung & 2.669 & 1.437 & 100 & 53.84 & 58.97 & 1.685 & 1.095 & 1.685 & 0 & & 0.65 \\
\hline-18 & Pasir Berlangu Berlanpumg & 2.749 & 1.218 & 100 & 4431 & 54.91 & 1.789 & 1.239 & 1.789 & 0 & & 0.871 \\
\hline .21 & Pasir Berlangu Berlanpumg & 2.637 & 1.234 & 100 & 46.8 & 55.24 & 1.733 & 1.18 & 1.733 & 0 & & 1.15 \\
\hline .24 & Lempung & 2.615 & 1.297 & 100 & 49.6 & 56.46 & 1.703 & 1.138 & 1.703 & 0 & & 0.93 \\
\hline .27 & Lempung Berpasir & 2.628 & 1.207 & 100 & 45.93 & 54.69 & 1.738 & 1.191 & 1.738 & 0 & & 1.649 \\
\hline-30 & Pasir Berlanau Berkerikil & 2.549 & 0.948 & 100 & 37.19 & 48.67 & 1.795 & 1.309 & 1.795 & 38 & 0 & \\
\hline-33 & Pasir Berlanau Berlampung & 2.644 & 0.847 & 100 & 32.03 & 45.86 & 1.89 & 1.432 & 1.89 & 0 & & 2.15 \\
\hline-36 & Pasir Berlangu Berlennumg & 2.694 & 0.867 & 100 & 32118 & 46.44 & 1.907 & 1.443 & 1.907 & 0 & & 2.6 \\
\hline
\end{tabular}

Tabel 1.

\section{(lanjutan)}

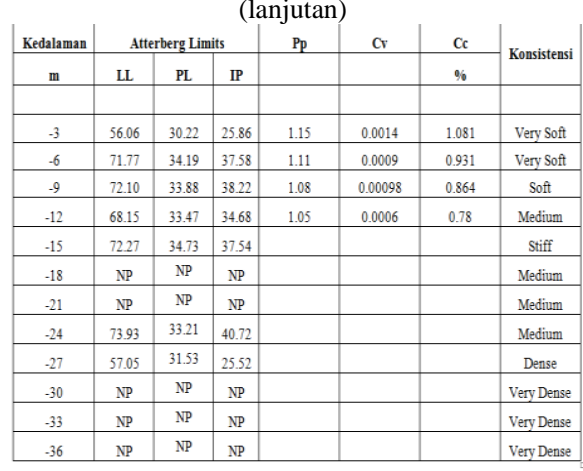

\section{B. Perencanaan Pondasi Rakit}

1. Daya dukung Pondasi Rakit

Pondasi rakit direncanakan dengan dimensi 44 x 42 meter pada kedalaman $3 \mathrm{~m}$. Daya dukung pondasi rakit dihitung [1] sebagai berikut :

Diketahui parameter tanah pada kedalaman 3 meter

$\mathrm{Cu}=11.198 \mathrm{kN} / \mathrm{m}^{2}$

$\gamma \mathrm{d}=10.83 \mathrm{kN} / \mathrm{m}^{3}$

Untuk $\varnothing=0$

$\mathrm{Nc}=5.14$

$\mathrm{Nq}=1$

$\mathrm{N} \gamma=0$

Maka, $\mathrm{q}_{\mathrm{u}}=\left(1-0.2 \frac{\mathrm{B}}{\mathrm{L}}\right) \mathrm{cNc}+\mathrm{qNq}+\left(1-0.2 \frac{\mathrm{B}}{\mathrm{L}}\right) \frac{1}{2} \gamma \mathrm{BN} \gamma$

$q_{(\text {all })}=\frac{\left(1-0.2 \frac{32}{30}\right) 11.198 \times 5.14}{3}+10.83 \times 3 \times 1=55.752$

$\mathrm{kN} / \mathrm{m}^{2}$ $\mathrm{q}_{\text {all }}=5.575 \mathrm{t} / \mathrm{m}^{2}$

\section{Tekanan Pada Tanah}

Tekanan pada tanah dibawah pondasi dihitung dengan perumusan berikut ini [2].

$\mathrm{q}=\frac{\mathrm{Q}}{\mathrm{A}} \pm \frac{\mathrm{M}_{\mathrm{y}} \mathrm{x}}{\mathrm{I}_{\mathrm{y}}} \pm \frac{\mathrm{M}_{\mathrm{x}} \mathrm{y}}{\mathrm{I}_{\mathrm{x}}}$

karena beban simetris maka tidak ada momen arah $\mathrm{x}$ dan arah y, maka :

$\mathrm{q}=\frac{9564}{1760} \pm 0 \pm 0$

$\mathrm{q}=5.434 \mathrm{t} / \mathrm{m}<\mathrm{q}_{\text {all }}=5.575 \mathrm{t} / \mathrm{m}^{2}$

3. Perencanaan Struktur Pondasi Rakit

a) Perencanaan Pelat

Perhitungan pelat direncanakan pelat dua arah sesuai dengan peraturan SNI 2847:2013 [4]. Hasil perencanaan pelat lantai dapat dilihat pada tabel-tabel berikut :

$$
\text { Tabel } 2 .
$$

Hasil perencanaan pelat pondasi rakit

\begin{tabular}{|c|c|}
\hline Pelat & $400 \mathrm{~mm}$ \\
\hline \multicolumn{2}{|c|}{ Tulangan } \\
\hline Arah X & D22-250 \\
\hline Arah Y & D22-325 \\
\hline
\end{tabular}

b) Perencanaan Balok

Perhitungan penulangan lentur untuk komponen balok sesuai SNI 2847-2013 [4]. Hasil perencanaan pennulangan balok induk dapat dilihat pada tabel-tabel berikut : Tabel 3.

Hasil perencanaan balok pondasi rakit

\begin{tabular}{cc}
\hline Ukuran Balok & $\mathbf{6 0 0} \times \mathbf{9 0 0} \mathbf{~ m m}$ \\
\hline Tulangan \\
Tulangan Lentur Tarik & 7D25 \\
Tulangan Lentur Tekan & 4D25 \\
\hline
\end{tabular}

4. Penurunan Pondasi Rakit

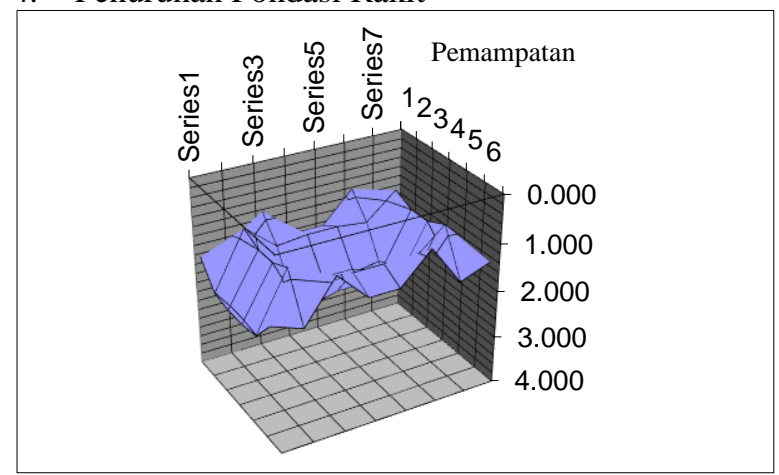

Gambar 1. Pemampatan Pondasi Rakit

Gambar 1 merupakan nilai pemampatan pada tanah dasar yang terjadi akibat beban[3]. Dimana sumbu x dan z pada gambar merupakan titik tinjauan bangunan arah memanjang dan melintang sedangkan sumbu y merupakan nilai pemampatan. Dapat dilihat pada gambar bahwa dengan beban maka dihasilkan nilai pemampatan yang jauh berbeda dari toleransi (NAVAC, DM7).

\section{Perbaikan Tanah dengan PVD}

Lapisan tanah kompresibel sebesar $12 \mathrm{~m}$ dari permukaan tanah. Sedangkan waktu yang dibutuhkan untuk memampat 
selama 10.82 tahun sehingga untuk menghilangkan consolidation settlement maka dilakukan perbaikan tanah dengan menggunakan PVD. Untuk masa waktu perbaikan 2 bulan 3 minggu diperlukan PVD dengan jarak 1.1 meter dengan tebal $5 \mathrm{~mm}$ dan tebal $100 \mathrm{~mm}$.

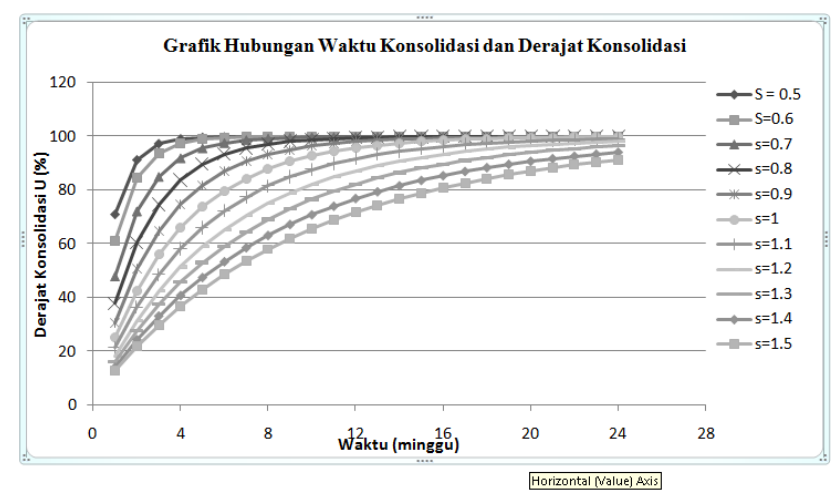

Gambar 2. Grafik hubungan waktu konsolidasi dengan derajat konsolidasi

6. Preloading

Preloading umumnya dikombinasikan dengan PVD untuk mempercepat konsolidasi. Hasil perhitungan $\mathrm{H}_{\text {final }}$ untuk ketinggian bervariasi adalah sebagai berikut.

Tabel 4.

Hasil perhitungan $\mathrm{H}_{\text {final }}$ untuk ketinggian timbunan bervariasi

\begin{tabular}{|c|c|c|c|c|}
\hline $\begin{array}{c}\mathrm{H} \\
\text { rencana }\end{array}$ & $\begin{array}{c}\mathrm{q} \\
\text { rencana }\end{array}$ & H inisial & $\mathrm{Sc}$ & Hfinal \\
\hline$(\mathrm{m})$ & $(\mathrm{t} / \mathrm{m} 2)$ & $(\mathrm{m})$ & $(\mathrm{m})$ & $(\mathrm{m})$ \\
\hline 3 & 67.5 & 3.255 & 0.574 & 2.681 \\
\hline 5 & 112.5 & 5.465 & 1.046 & 4.419 \\
\hline 7 & 157.5 & 7.705 & 1.586 & 6.119 \\
\hline 9 & 202.5 & 9.892 & 2.006 & 7.885 \\
\hline 11 & 247.5 & 12.045 & 2.350 & 9.694 \\
\hline 13 & 292.5 & 14.174 & 2.642 & 11.532 \\
\hline 15 & 337.5 & 16.286 & 2.895 & 13.392
\end{tabular}

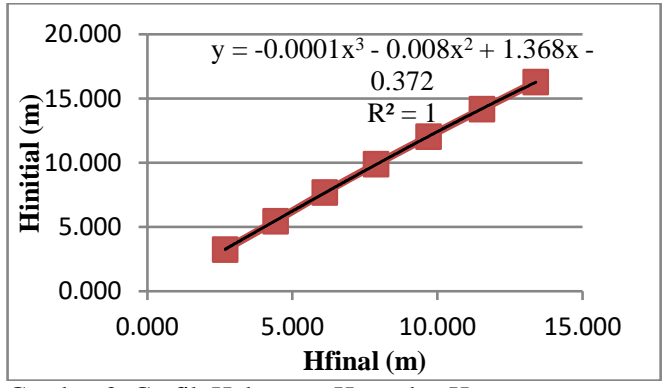

Gambar 3. Grafik Hubungan $\mathrm{H}_{\text {initial }}$ dan $\mathrm{H}_{\text {final }}$

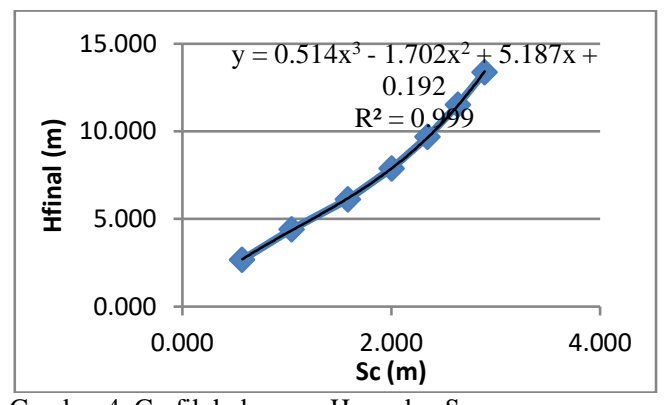

Gambar 4. Grafik hubungan $\mathrm{H}_{\text {initial }}$ dan $\mathrm{Sc}$

Akibat beban bangunan menimbulkan Scprimary konsolidasi $=214.1 \mathrm{~cm}$. Scsecondary diasumsikan 0.25 Scprimary. Maka Sc akibat penurunan konsolidasi $=1.25 \mathrm{x}$ $214.1 \mathrm{~cm}=267.65 \mathrm{~cm}$. Maka tinggi timbunan yang dibutuhkan untuk preloading adalah
$\mathrm{Sc}=2.677 \mathrm{~m}$

$\mathrm{H}$ final $=0.514(2.6773)-1.702(2.6772)+5.187(2.677)-$

$0.192=11,357 \mathrm{~m}$

Hinitial $=-0.0001(11.3573)+0.008(11.3572)+$ $1.243(11.357)-0.372=14.630 \mathrm{~m}$

\section{Perencanaan Pondasi Tiang Pancang}

Spesifikasi tiang pancang untuk perencanaan pondasi tiang sebagai berikut :

- Jenis Tiang pancang

- Kelas

: Tiang Pancang Bulat

- Diameter

$: \mathrm{B}$

- Panjang

- Luas Penampang

: $600 \mathrm{~mm}$

: $6-19 \mathrm{~m}$

- Modulus Inertia

: $1570.80 \mathrm{~cm} 2$

- Keliling

- Kuat tekan beton, f'c

- Allowable Axial

: $510,508.81 \mathrm{~cm} 4$

$: 188.4 \mathrm{~cm}$

: $52 \mathrm{Mpa}$

: 238.3 Ton

- Bending Moment

Crack

: 25 t.m

Ultimate

: 45 t.m

$: 131.1 \mathrm{t}$

1. Daya Dukung Tiang Pancang

a) Daya Dukung Tiang berdasarkan sondir [6].

Perhitungan daya dukung dengan cara Schmertmann and Nottingham (1975). Perhitungan dilakukan pada setiap kedalaman dan titik borhole. Berikut hasil perhitungan daya dukung :

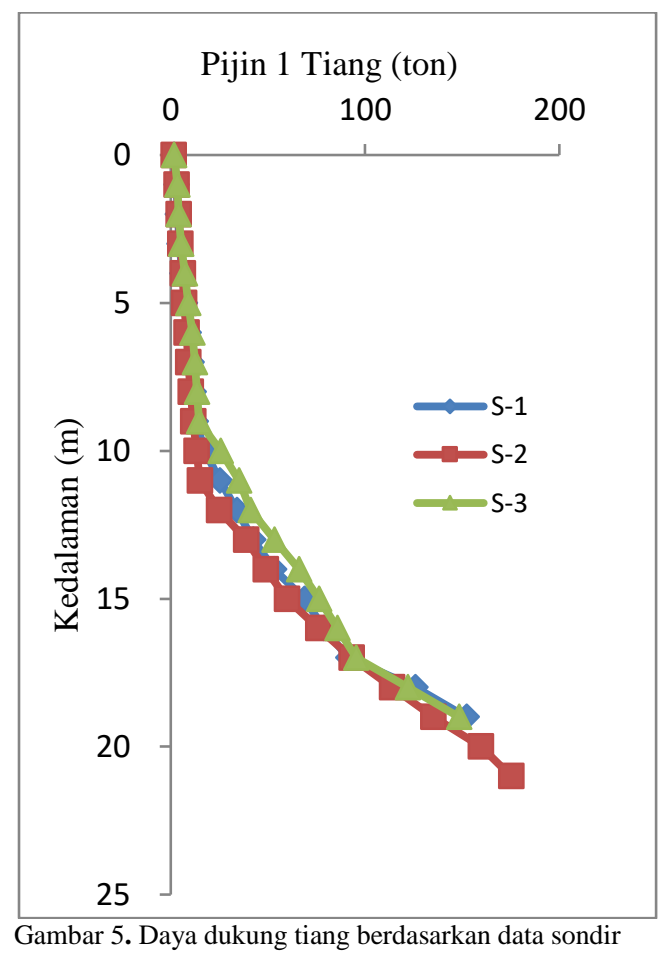

b) Daya Dukung Tiang berdasarkan SPT[6].

Perhitungan daya dukung berdasarkan data SPT dan borlog dengan cara Meyerhof dan Bazaara. Berikut adalah hasil perhitungan daya dukung berdasarkan data SPT. 


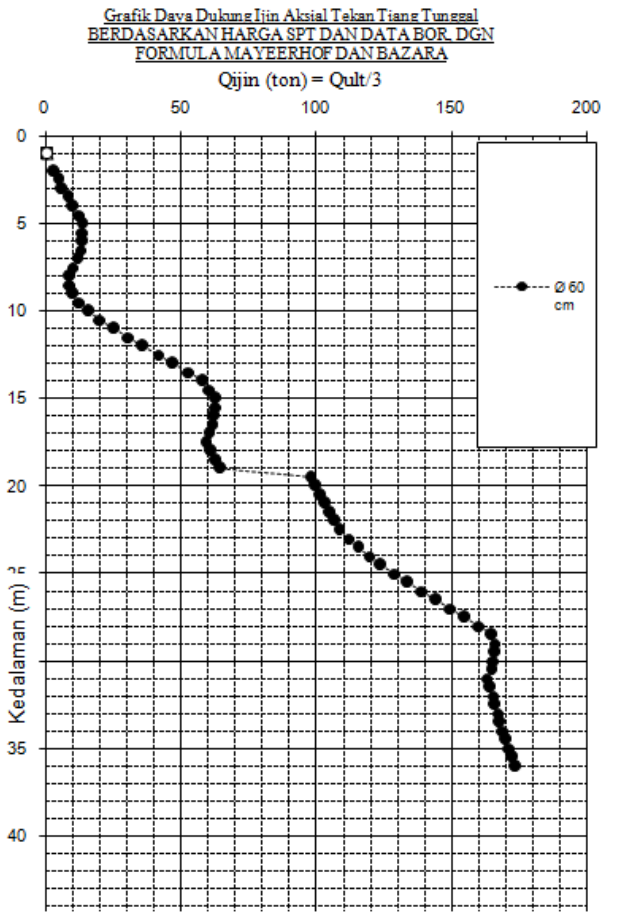

Gambar 6. Daya dukung Tiang berdasarkan data SPT

\section{Kedalaman Pondasi Tiang}

Qallowable bahan tiang diketahui 238.3 ton, dan nilai 1/2 Qallowable bahan adalah 119.15 ton. Daya dukung tanah ijin didapat pada kedalaman 24 meter dengan Qijin tanah sebesar 119.6 ton. Namun melihat profil tanah pada kedalaman 30 meter telah mencapai tanah keras. Maka tiang diteruskan sampai pada kedalaman 30 meter. Adapun nilai daya dukung ijin tanah pada kedalaman 30 meter sebagai berikut :

Qultimate tanah $=165.67$ ton

$\mathrm{SF}=3$

\section{Konfigurasi Pondasi}

Berdasarkan perhitungan kebutuhan pondasi tiap joint yang direncanakan, maka didapatkan beberapa jenis pilecap. Tipe pilecap yang ada berdasarkan kebutuhan jumlah tiang pancang yang direncanakan dapat dilihat pada Tabel 5 . Gambar tipe pilecap dan juga konfigurasi pondasi untuk seluruh bangunan dapat dilihat pada Lampiran 5. Tabel 5.

Konfigurasi Pondasi Tiang

\begin{tabular}{cccc}
\hline \hline Type & Dia & $\mathbf{n}$ & S \\
\hline PC-1 & 600 & 2 & $3 \mathrm{~d}$ \\
PC-2 & 600 & 4 & $3 \mathrm{~d}$ \\
PC-4 & 600 & 6 & $3 \mathrm{~d}$ \\
\hline \hline
\end{tabular}

4. Gaya Horizontal pada Tiang

Setelah direncanakan untuk dapat menahan gaya-gaya reaksi diperletakan, pondasi tiang pancang juga perlu dikontrol terhadap gaya horizontal. Defleksi dan momen yang terjadi pada tiang pancang tidak boleh melebihi batasan yang telah ditentukan. Berikut adalah contoh perhitungan kontrol terhadap pondasi untuk type-1:

a) Mencari harga $\mathrm{f}$

Harga f didapatkan dari grafik NAVFAC DM-7 yang telah tercantum pada Gambar 2.4. Nilai f ditentukan berdasarkan nilai qu.

$\mathrm{qu}=2 \mathrm{cu}=2 \times 0.0992=0.198 \mathrm{~kg} / \mathrm{m}^{2}$

Didapatkan nilai $\mathrm{f}=2.5 \mathrm{ton} / \mathrm{ft} 3=0.08 \mathrm{~kg} / \mathrm{cm} 3$

$$
\begin{aligned}
& \text { - } \quad \text { Menentukan nilai T } \\
& \mathrm{T}=\left(\frac{\mathrm{EI}}{\mathrm{f}}\right)^{\frac{1}{5}}=\left(\frac{338921.82 \times 510508.81}{0.08}\right)^{\frac{1}{5}}=293.091 \mathrm{~cm}
\end{aligned}
$$

b) Menentukan nilai F $\delta$ dan FM

Untuk menentukan nilai $\mathrm{F} \delta$ dan FM dapat digunakan grafik NAVFAC DM-7 yang tercantum pada Gambar 2.6.

Nilai $\mathrm{F} \delta$ dan FM didapatkan berdasarkan nilai $\mathrm{L} / \mathrm{T}$, dimana $\mathrm{L}$ adalah panjang sebuah tiang yang digunakan.

$\mathrm{L} / \mathrm{T}=22 / 293.091 \mathrm{~cm}=7.056$

Didapatkan dari Gambar 2.6: F $\delta=0.96$ dan FM $=-0.865$

c) Menentukan nilai defleksi $(\delta \mathrm{P})$ pada tiang

Defleksi terbesar yang terjadi pada tiang berada di bagian paling atas tiang. Besarnya defleksi dapat dihitung dengan persamaan berikut :

$$
\delta_{\mathrm{p}}=\mathrm{F}_{\delta}\left(\frac{\mathrm{PT}^{3}}{\mathrm{EI}}\right) \quad=\left(\frac{338921.82 \times 510508.81}{0.08}\right)^{\frac{1}{5}}=0.0312 \mathrm{~mm}
$$

Keterangan :

$\mathrm{P}: \mathrm{Fy} / \mathrm{n}$

$\mathrm{n}:$ Jumlah tiang dalam satu grup

$\mathrm{T}$ : Faktor kekakuan relatif

E : Modulus elastisitas tiang

I : Momen Inersia dari potongan melintang tiang $\delta \mathrm{P}<1$ inch $(2.54 \mathrm{~cm})$

d) Menentukan nilai momen (Mp) pada tiang

Momen terbesar yang terjadi pada tiang berada di bagian paling atas tiang. Besarnya momen

$$
\begin{aligned}
& M_{p}=F_{m} P T \\
& M_{p}=0.865 \times 0.224 \times(293.091 / 100)=0.567 \text { t.m } \\
& M p<\text { Mcrack tiang }
\end{aligned}
$$

Hasil perhitungan defleksi dan momen dapat dilihat pada tabel berikut :

Tabel 6.

Defleksi dan Momen pada tiang

\begin{tabular}{cccc}
\hline \hline Type & $\begin{array}{c}\text { Dia } \\
(\mathbf{m m})\end{array}$ & Defleksi(mm) & Momen (t.m) \\
\hline PC-1 & 600 & 0.0312 & 0.567 \\
PC-2 & 600 & 18.711 & 3.396 \\
PC-3 & 600 & 20.814 & 3.778 \\
\hline \hline
\end{tabular}

5. Elastic Settlement Pondasi Tiang Group

Perhitungan penurunan1 tiang yang dibebani beban kerja dihitung dengan persamaan berikut[2].

$\operatorname{se}=\operatorname{se}_{(1)}+\operatorname{se}_{(2)}+\operatorname{se}_{(3)}$

$\mathrm{P}_{\text {ijin }}$

$=119.15$ ton

Beban tiang dukung ujung, $\mathrm{Q}_{\mathrm{ws}} \quad=80.22$ ton $=802.2 \mathrm{kn}$

Beban tiang geser friksi,

$\mathrm{Q}_{\mathrm{wp}}=119.15-80.22$

Modulus Elastisitas tiang,

$E_{p}=4700 \sqrt{ } 52$

$=38.93 \mathrm{ton}=389.3 \mathrm{kn}$

$\xi$

Luas penampang tiang, $A_{p}$

Panjang tiang, $\mathrm{L}$

Diameter

$\mathrm{q}_{\mathrm{wp}}=\mathrm{Q}_{\mathrm{wp}} / \mathrm{A}_{\mathrm{p}}$

$\mu_{\mathrm{s}, \text { poisson ratio }}$

Faktor pengaruh, Iwp

Modulus Elastisitas tanah, Es

keliling tiang, $\mathrm{p}$

$=33892.182 \mathrm{~N} / \mathrm{mm}$

$=33892182 \mathrm{kn} / \mathrm{m}^{2}$

$=0.6$

$=0.15708 \mathrm{~m}^{2}$

$=28 \mathrm{~m}$

$=0.6 \mathrm{~m}$

$=2478.355 \mathrm{kn} / \mathrm{m}^{2}$

$=0.4$

$=0.85$

$=80000 \mathrm{kn} / \mathrm{m}^{2}$

$=1.885 \mathrm{~m}$

Faktor pengaruh, Iws dihitung dengan rumus :

Iws $=2+0.35 \sqrt{ } \mathrm{L} / \mathrm{D} \quad=4.391$ 
$\mathrm{S}_{\mathrm{e}(1)}=\frac{(\mathrm{Qwp}+\xi \mathrm{Qws}) \mathrm{L}}{\mathrm{ApEp}}=\frac{(389.3+0.6 \times 802.2) 28}{0.157 \times 33892182}=0.0026 \mathrm{~m}$

$\mathrm{S}_{\mathrm{e}(2)}=\frac{\mathrm{q}_{\mathrm{wp}} \mathrm{D}}{\mathrm{Es}}\left(1-\mu_{\mathrm{s}}^{2}\right) \mathrm{I}_{\mathrm{wp}}=\frac{2478.355 \times 0.6}{80000}\left(1-0.4^{2}\right) 0.85=$ $0.01327 \mathrm{~m}$

$\mathrm{S}_{\mathrm{e}(3)}=\left(\frac{\mathrm{Q}_{\mathrm{ws}}}{\mathrm{pL}}\right) \frac{\mathrm{D}}{\mathrm{E}_{\mathrm{s}}}\left(1-\mu_{\mathrm{s}}^{2}\right) \mathrm{I}_{\mathrm{ws}}=\left(\frac{802.2}{1.885 \times 28}\right) \frac{0.6}{80000}(1-$ $\left.0.4^{2}\right)=0.00042 \mathrm{~m}$

Jadi, total elastic settlement pondasi tiang adalah se $=\mathrm{se}_{(1)}+$ $\mathrm{se}_{(2)}+\mathrm{se}_{(3)}=0.016297 \mathrm{~m}=1.63 \mathrm{~cm}$

Elastic Settlement group tiang dihitung dengan rumus Vesic $\mathrm{Bg}=(2 \times 1.8)+0.6=2.4 \mathrm{~m}$

$S_{g(e)}=\sqrt{\frac{B_{g}}{D}} S e=\sqrt{\frac{2.4}{0.6}} \times 16.297=32.6 \mathrm{~mm}=0.0326 \mathrm{~m}$

Tabel 7.

Elastic Settlement Tiang

\begin{tabular}{cc}
\hline \hline Type & Sg (m) \\
\hline PC-1 & 0.0163 \\
PC-2 & 0.0326 \\
Pc-3 & 0.0326 \\
\hline \hline
\end{tabular}

\section{Perhitungan Biaya Bahan}

Dari perhitungan biaya material didapatkan untuk pondasi tiang pancang dan pondasi rakit sebagai berikut : Tabel 8.

Perhitungan harga bahan Tiang Pancang

\begin{tabular}{|c|c|c|c|c|c|}
\hline & Uraian & Volume & Unit & $\begin{array}{l}\text { Harga } \\
\text { Satuan }\end{array}$ & Biaya total \\
\hline 1 & Tiang Pancang D60 & 3136 & $\mathrm{~m}$ & $750,000.00$ & $2,352,000,000.00$ \\
\hline 2 & Beton Mutu fc 40 Mpa & & & & \\
\hline & $\mathrm{PC}-1$ & 19.344 & m3 & $1,150,000.00$ & $22,245,600.00$ \\
\hline & $\mathrm{PC}-2$ & 86.4 & m3 & $1,150,000.00$ & $99,360,000.00$ \\
\hline & $\mathrm{PC}-3$ & 92.16 & $\mathrm{~m}_{3}$ & $1,150,000.00$ & $105,984,000.00$ \\
\hline 3 & Tulangan & & & & \\
\hline & $\varnothing 12_{12}$ & 44.054 & $\mathrm{~kg}$ & $9,000.00$ & $396,482.23$ \\
\hline & D16 & 300.768 & $\mathrm{~kg}$ & $9,000.00$ & $2,706,909.63$ \\
\hline & D19 & 94.103 & $\mathrm{~kg}$ & $9,000.00$ & $846,923.59$ \\
\hline & $\mathrm{D} 25$ & 734.296 & $\mathrm{~kg}$ & $9,000.00$ & 6.608.666.09 \\
\hline
\end{tabular}

Tabel 9.

Perhitungan Harga Bahan Pondasi Rakit

\begin{tabular}{|c|c|c|c|c|c|}
\hline & Eraian & Volume & Tnit & $\begin{array}{l}\text { Harga } \\
\text { Satuan }\end{array}$ & Biaya total \\
\hline 1 & $\begin{array}{l}\text { Beton Sifutu fe } 40 \\
\text { Mpa }\end{array}$ & 910.4 & $\mathrm{~m}^{3}$ & $1,150,000,00$ & $1,046,960,000.00$ \\
\hline \multirow[t]{4}{*}{2} & Tulangan & & & & \\
\hline & D13 & 537.65 & $\mathrm{k}=$ & 9.000 .00 & $4,838,808,71$ \\
\hline & $\mathrm{D} 22$ & $10,240.27$ & $\mathrm{~kg}$ & 9.000 .00 & $93,782,465.13$ \\
\hline & D25 & 8.138 .29 & $\mathrm{~kg}$ & $9,000.00$ & $73,244,651.92$ \\
\hline 3 & PVD & 19,188 & $\mathrm{~m}$ & $3,500.00$ & $07,158,000,00$ \\
\hline & \multicolumn{4}{|l|}{\begin{tabular}{|l|l} 
Iotal \\
\end{tabular}} & $1,285,983,035,76$ \\
\hline
\end{tabular}

\section{PENUTUP}

1. Pada disain pondasi tiang pancang menggunakan tiang pancang bulat D60 direncanakan 3 tipe konfigurasi tiang pancang dengan kedalaman 30 meter (N-SPT 50). Settlement yang terjadi adalah immediete settlement atau elastic settlement dengan batasan yang diijinkan.

2. Pada disain pondasi rakit direncanakan pada kedalaman 3 meter dengan dimensi 44 x 42 meter dengan tebal plat 40 $\mathrm{cm}$ dan perkuatan balok 60/90 cm. Differential settlement melebihi batas toleransi 0.0015 (NAFVAC, DM-7).

3. Untuk menghilangkan settlement pada pondasi rakit dibutuhkan perbaikan tanah. Waktu yang dibutuhkan untuk memampat jika tidak menggunakan PVD yaitu selama 10.82 tahun sehingga untuk menghilangkan consolidation settlement maka dilakukan perbaikan tanah dengan menggunakan PVD dengan kombinasi preloading. Untuk masa waktu perbaikan 2 bulan 3 minggu diperlukan PVD dengan jarak 1.1 meter dengan tebal $5 \mathrm{~mm}$ dan tebal $100 \mathrm{~mm}$.

4. Biaya bahan dari kedua jenis pondasi adalah :

- $\quad$ Pondasi Tiang $=\operatorname{Rp} 2,590,148,581.54$

- $\quad$ Pondasi Rakit $=$ Rp 1,285,983,935.76

Maka alternatif yang disarankan adalah menggunakan tiang pancang walaupun dari harga material lebih mahal dibandingkan pondasi rakit tetapi pada pondasi tiang tidak diperlukan perbaikan tanah terlebih dahulu karena penurunan tanah (settlement) tidak menjadi masalah. Sedangkan jika menggunakan pondasi rakit perlu dilakukan perbaikan tanah terlebih dahulu. Perbaikan tanah dengan PVD dan preloading timbunan membutuhkan material timbunan yang cukup besar sehingga tidak efektif digunakan pada proyek tersebut.

Pondasi rakit bisa jadi alternatif pilihan karena lebih ekonomis dibandingkan pondasi tiang pancang. Pondasi rakit dapat digunakan jika daya dukung tanah di permukaan cukup baik. Untuk perbaikan tanah dengan PVD dan preloading dengan timbunan membutuhkan mobilisasi alat berat dan material timbunan yang banyak sehingga perlu dipikirkan untuk penggunaan vacuum preloading maupun kombinasi vacuum preloading dan timbunan jika beban vacuum tidak mencukupi.

\section{DAFTAR PUSTAKA}

[1] Das, Braja M. (translated by Mochtar N.E, and Mochtar I.B.). 1985. Mekanika Tanah (Prinsip-prinsip Rekayasa Geoteknik) Jilid II. Jakarta: Erlangga.

[2] Das, Braja M. 2011. Principles of Foundation Engineering 7th Edition. USA: Cengage Learning.

[3] Kumalasari, Putu Tantri. 2008. Analisa Pemodelan 3 Dimensi Sistem Struktur Gedung Dengan Pondasi Dangkal Di Atas Tanah Lunak Yang Mengakibatkan Penurunan Konsolidasi Merata. Surabaya: Institut Teknologi Sepuluh Nopember.

[4] SNI 2847-2013. Tata Cara Perencanaan Struktur Beton Untuk Bangunan Gedung.

[5] Wahyudi, Herman. 1999. Daya Dukung Pondasi Dalam. Surabaya: Jurusan Teknik Sipil FTSP ITS. 